\title{
Morphology and environment in the Jurassic Nucleatidae (Brachiopoda) from Western Tethys
}

\author{
JORGE COLÁS AND FERNANDO GARCÍA JORAL
}

\begin{abstract}
Nucleatidae (Brachiopoda, Terebratulida) are commonly considered as typical members of the Mediterranean assemblages during the Jurassic. However, nucleatids occasionally also occur in the margins of Western Tethys (Northwestern European shelf). Some of these occurrences in northeastern Spain are analysed, detecting a relation between nucleatid morphology and palaeoenvironment during the Jurassic. The validity of this relationship for the whole of the representatives of the group in the Western Tethys dur- ing the Jurassic is tested by means of morphofunctional analyses (principal components analysis and discriminant analysis), concluding that reduction of the lateral expansion of the shell is the key morphological feature whereby epioceanic and epicontinental taxa differ. This change can have functional significance because it can be interpreted as a mechanism to reduce the area exposed when the valves gape, increasing protection against harmful particles in environments characterized by higher terrigenous input. Some modifications on the systematics of the Nucleatidae at the genus level are proposed on the basis of the temporal and biogeographical distribution of these adaptations.

Brachiopods, Nucleatidae, functional, morphology, adaptation, systematics, Jurassic, Spain.
\end{abstract}

Jorge Colás [jcolas@unizar.es] Departamento de Ciencias de la Tierra (Paleontología) - IUCA, Universidad de Zaragoza, Pedro Cerbuna 12, 50009 Zaragoza, Spain; Fernando García Joral [fgjoral@geo.ucm.es], Departamento y UEI de Paleontología, Facultad de Cien- cias Geológicas, Universidad Complutense de Madrid e Instituto de Geología Económica, CSIC, José Antonio Novais 2, 28040 Madrid, Spain; manuscript received on 30/9/2010;

Nucleatids, in addition to other groups such as pygopids and sulcate rhynchonellides, are typical components of the brachiopod fauna that characterized the Mediterranean Province during the Jurassic (Ager 1959, 1960, 1967, 1971, 1973; Ager \& Walley 1977; Ager \& Sun 1989; Manceñido 1993, 2002; Vörös 1993, 2005). The opening of the Ligurian-Penninic oceanic belt and subsequent detachment of a Mediterranean micro-continent from the European plate in the Early Jurassic have been alleged by Vörös (1977, 1988, 1993, 2005) as the causes for the biogeographical differentiation of this fauna. Therefore, the records of nucleatids outside of the Mediterranean domain have been widely interpreted as indicators of time intervals characterized by enhanced migration between the different palaeobiogeographical provinces.

Ager \& Walley (1977), Ager (1986, 1993), Vörös (1977, 1993, 2005), Manceñido (1993) and Harper et al. (2005) alleged that larval dispersion by means of ocean currents, combined with seamount hopping (Zezina 1976, 1985), could explain the exceptional occurrences of nucleatids as far as in the southwestern Pacific in the Early and Late Jurassic (Manceñido 1993) and in northeastern Greenland in the Early
Cretaceous (Owen 1976; Harper et al. 2005). Tchoumatchenco (1986) also suggested the dispersion of nucleatids as epiplanktonic organisms attached to ammonoid shells, which would permit longer migration periods allowing the travelling of not only larval specimens, but also adult forms. In any case, these dispersal mechanisms are random and they can be considered a negligible faunal connection between the palaeobiogeographical domains (Vörös 1977). However, the occurrence of nucleatids and other groups of Mediterranean brachiopods at the margins of the Western Tethys became quite common during the Middle Jurassic, being remarkable in Callovian and Oxfordian times. Contrarily, nucleatids are extremely scarce in the Mediterranean domain during those same periods, probably due to the unfavourable conditions evidenced by the general deposition of radiolarites (De Wever 1989; Vörös 2005). To explain this palaeobiogeographical shift Vörös (1993) suggested a gradual invasion of these areas favoured by a combination of oceanic surface current acceleration, related to the opening of the Hesperian Strait between the African craton and Iberia, and the function of the Tisza micro-plate as an 'invasion base'. 
Although the dispersion mechanisms summarized above could explain the arrival of nucleatids to 'circum-Mediterranean' domains (Northwestern European and Northern African shelves), it is important to keep in mind that at these areas, nucleatids had to survive in environmental conditions which were notably different to those at the Mediterranean domain, which is the typical distributional area of the group. Because of its location at the internal part of the Western Tethys, the Mediterranean Province is dominated by epioceanic conditions, meaning almost negligible terrigenous input and reduced nutrient supply from the continent (Hallam 1971; Oló riz 2000). The epicontinental conditions that mainly characterize 'circumMediterranean' domains are more heterogeneous, but generally imply notably higher nutrient and terrigenous supply. Such differences would prevent a lasting settlement of those non-adapted nucleatids in the new domains. The colonization of the epicontinental platforms of the Western Tethys by nucleatids during the Jurassic should therefore have involved an adaptive process. The aim of this article is to test whether morphological changes in shell shape correlate with differences in biogeographical and environmental distribution, and whether they are consistent with adaptive processes within the theoretical morphofunctional framework previously proposed for the Nucleatidae.

\section{Functional morphology of nucleatids}

The typical morphology of Nucleatidae is characterized by the smoothness of the shell and the moderate to strong sulcation of the anterior commissure towards the ventral valve. It seems to be a rather stable and conservative morphology since it has been recorded with very few changes from the Early Jurassic (Hettangian) to the Late Cretaceous (Cenomanian). Such a conservative morphology might be related to adaptation to very stable environments. Within the Dyscoliidae, the only extant relatives of Nucleatidae at superfamily level, the genus Abyssothyris Thompson displays a similar morphology and is restricted to abyssal depths (Ager 1965; Cooper 1972; Zezina 1976). Several authors (Ager 1965 and Vörös 2005 among others) have assigned a similar environmental distribution for the Mesozoic forms from an actualistic point of view. However, the Mediterranean domain, which is the typical distributional area of the group, was neither extremely nor homogeneously deep. Ager (1965), Vogel (1966), Rudwick (1970), Emig (1992), Manceñido (1993) and other authors hypothesized that the sulcate and bilobate morphology of nucleatids is related to the adaptation to markedly deep, calm and poorly oxygenated environments with low food supply. This relation was explained by the increase in the efficiency of the current system implying that sulcation and bilobation would force the vertical and horizontal separation of inhalant and exhalant currents (Fig. 1), although this functionality has never been quantified. Separation of currents would be an advantage at epioceanic environments preventing the filtration of previously filtered water (which is impoverished in food and oxygen). In addition to dorsal sulcation and bilobation of the shell, nucleatids and pygopids are characterized by more or less laterally expanded shells. Bather (in Buckman 1906) and Ager (1965) considered this feature as an adaptation to oxygen-poor environments because it provides more space to the lophophore, thereby increasing respiration ability. Plectolophe lophophores can be reasonably inferred for the Mesozoic representatives of the group considering that this is the characteristic lophophore at $80 \%$ of living Terebratulidina species and 40\% of living Dyscolioidea (Emig 1992), including Abyssothyris Thomson (p. 9 in Cooper 1972;) previously stated as the present-day analogue of nucleatids (schizolophe is characteristic at $40 \%-$ Dyscolia species, and trocholophe at 20\% - Goniobrochus species). In plectolophe lophophores the tentacles of the lateral arms enclose the postero-lateral inhalant apertures and bear the main part of the fi on amount (Rudwick 1962; LaBarbera 1981; Emig 1992). Thus, the laterally expanded shells of the nucleatids and pygopids would not only accommodate larger lophophores enhancing the filtration of nutrients, the creation of water flow and the separation of inhalant and exhalant currents but also increase the area of the inhalant opening (Fig. 1). These modifi ations would be useful in the nutrient-poor environments where these terebratulides lived.

If, as previously hypothesized, the typical nucleatid morphology is the result of adaptation to epioceanic environments, a series of morphological changes should be expected following the colonization of epicontinental environments. The occurrences of Jurassic nucleatids at the epicontinental platforms of Eastern Iberia are analysed in the following section in an attempt to detect the existence of these changes.

\section{Jurassic nucleatids in Iberia}

In the Subbetic domain of the Betic Cordillera, at the epioceanic environments of the southeastern Iberian palaeomargin with strong Mediterranean affinity (Fig. 2A), occurrences of nucleatids along the whole Jurassic have been widely reported (e.g. Jiménez de Cisneros 1923, 1935; Sequeiros 1977; Baeza-Carratalá 


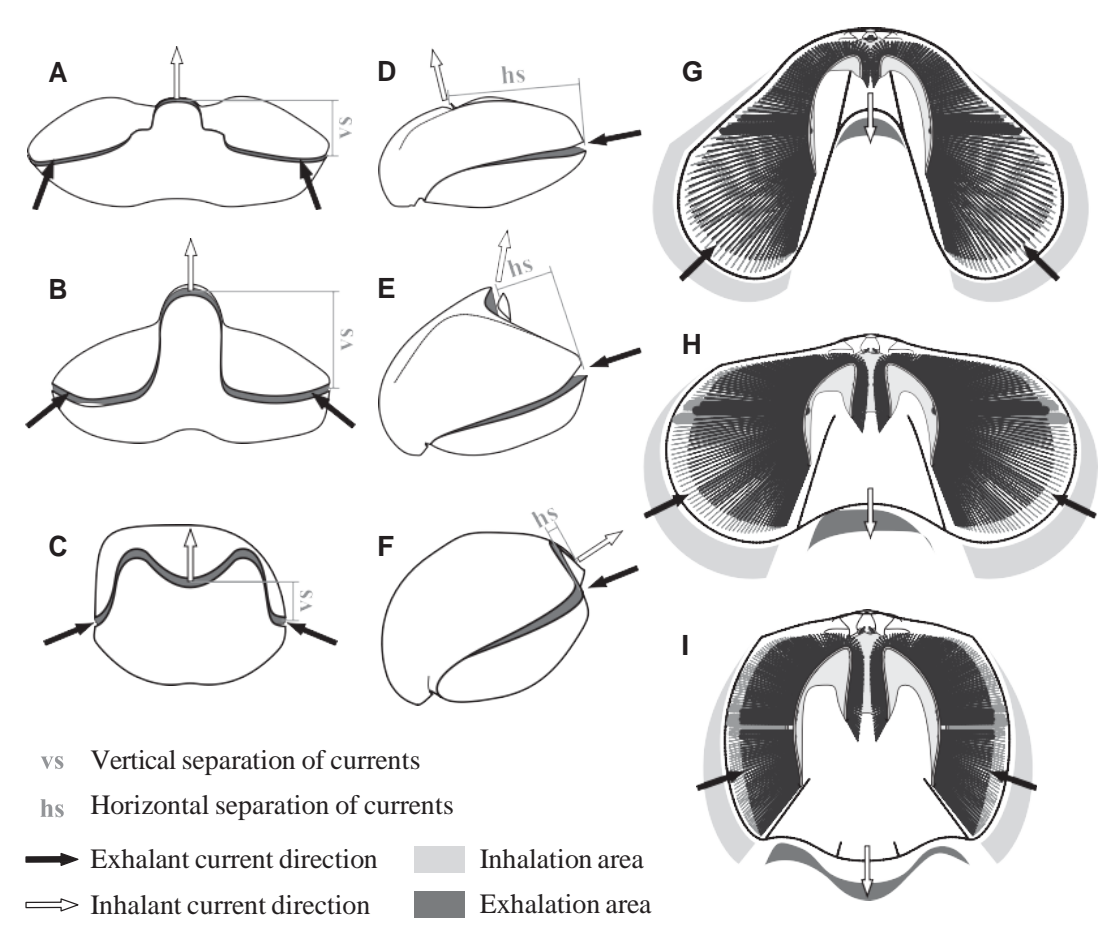

Fig. 1. Functional morphology of nucleatids and pygopids. A-F, vertical (A-C) and horizontal (D-F) separation of inhalant and exhalant currents in Pygope janitor (Pictet) (A, D), Linguithyris aspasia (B, E) and Kubanithyris bifrons (C, F) (based on Vogel 1966 and Rudwick 1970). Note the reduction in both dimensions displayed by K. bifrons. G-H, hypothetical placement of plectolophe lophophore and exposed area with open valves in P. janitor (G), L. aspasia (H) and K. bifrons (I). Note the larger size of the tentacles shown by the lateral arms of the lophophore and the greater exposed area in epioceanic taxa $(G, H)$ in comparison with epicontinental taxa (I). See the text for a more detailed explanation. (Not to scale.)

2004, 2008; among others). In the epicontinental environments with clear Northwestern European affinity that surround the Iberian Massif, the records of nucleatids are restricted to those of Dubar (1931) from the Middle Jurassic of the Basque-Cantabrian Basin, Choffat (1947) from the Middle and Late Jurassic of the Lusitanian Basin, and Reolid (2005) from the Late Jurassic of the Prebetic shelf (Fig. 2A). The record of nucleatids in the Eastern Iberia platform system is reported for the fi time in this article, specifically the occurrence of the Aalenian Linguithyris nepos (Canavari), the Callovian Kubanithyris bifrons (Oppel) and the Oxfordian Nucleata nucleata (Schlotheim).

\section{Geologicalsetting}

At the eastern margin of the Iberian Massif, marine sedimentation took place in a system of epicontinental carbonate platforms (Aragonese, Castilian and Tortosa platforms) during Middle and Late Jurassic (Gómez \& Fernández-Ló pez 2004, 2006) (Fig 2A). This domain marked the transition between the Mediterranean Tethys and the Central Atlantic during this period (Fernández-Ló pez et al. 1996; Aurell et al. 2002; Page et al. 2004; Gó mez \& Fernández-Ló pez 2006). Both the Castilian and Tortosa platforms were open to the infl ences of the Western Tethys and were connected with the Aragonese Platform by the Beceite Strait (located between the emerged Catalonian Massif and the shallow, temporarily emergent, Maestrazgo High). A way to the Central Atlantic was possible through the Soria Seaway (located between the Ebro and Iberian massifs) that connected the Aragonese Platform with the Basque-Cantabrian Basin.

The sediments deposited in the Castilian and Aragonese platforms form two bands with NW-SE subparallel alignment, which are known as the Aragonese and Castilian branches of the Iberian Range, respectively. The Jurassic sediments deposited at the Tortosa Platform are currently part of the Catalonian Coastal Range, disposed with a SW-NE alignment parallel to the coast of the Mediterranean Sea (Fig. 2B).

\section{The Aalenian case}

A single individual of L. nepos (Canavari) (Fig. 3A-C) has been recorded in bed 9TY128 of the L'Assut section at Tivenys (Tarragona Province) (Fig. 2B, D). Stratigraphically, it corresponds to the Tivenys Member of the Sant Blai Formation (Fernández-Ló pez et al. 1996, 1999), which is made up of wackestones to packstones, commonly containing variable proportions of ferruginous and / or phosphatic ooids and pisoids. This unit represents the time span 


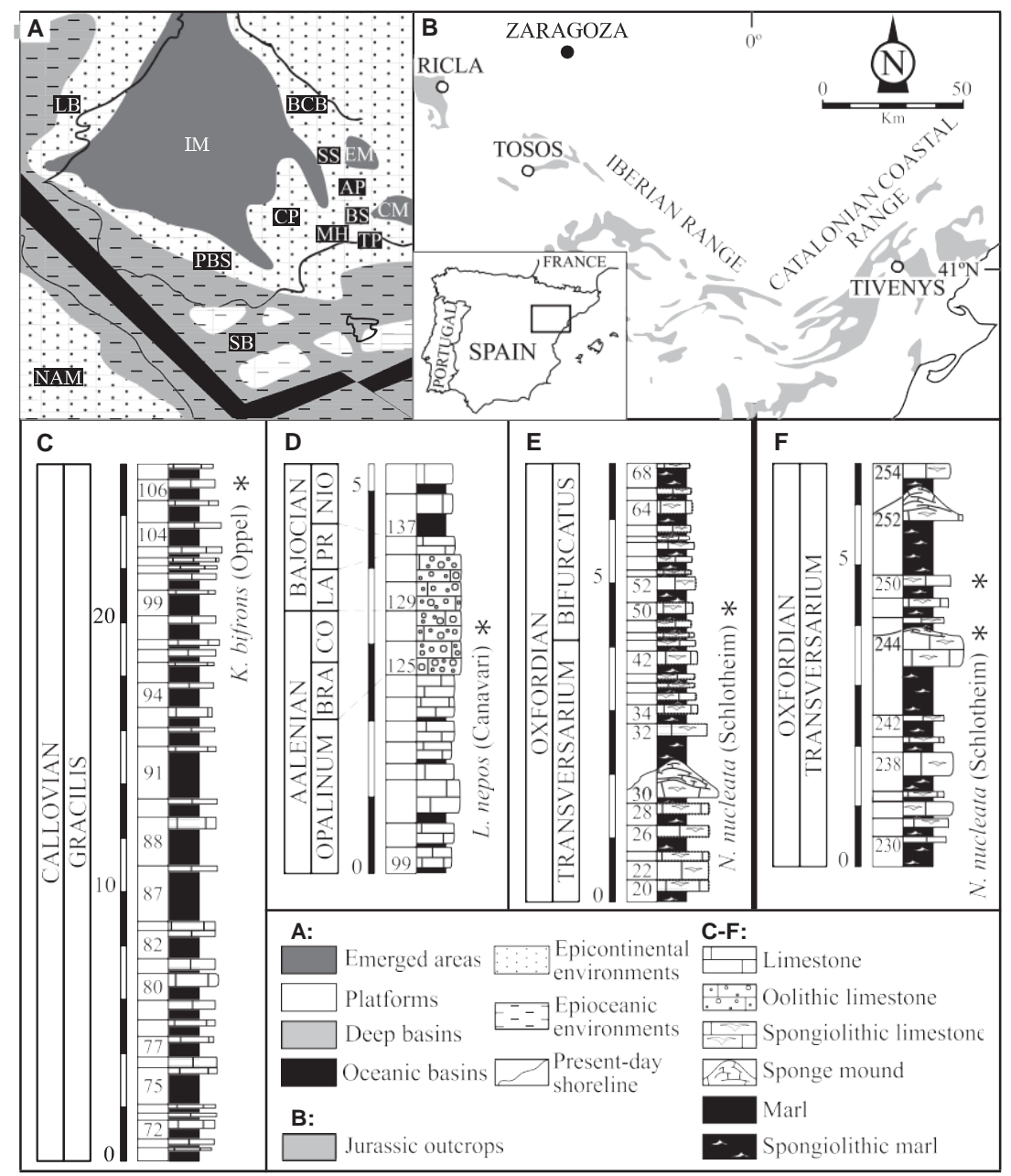

Fig. 2. Geological and geographical setting of the Jurassic nucleatid occurrences in Spain. A, distribution of palaeoenvironments at Eastern Iberia for Middle-Late Jurassic and main palaeogeographical features (adapted from Aurell et al. 2002; Martín-Algarra \& Vera 2004; Gómez \& Fernández-López 2006); AP= Aragonese Platform, BCB = Basque-Cantabrian Basin, BS = Beceite Strait, CM = Catalonian Massif, EM = Ebro Massif, LB = Lusitanian Basin, MH = Maestrazgo High, NAM = North African Margin, PBS = Prebetic shelf, $\mathrm{SB}=$ Subbetic zone, SS = Soria Seaway. B, outcrops of Jurassic rocks at Northern Iberian Range and Catalonian Coastal Range with the localities where the studied specimens were collected (modified from Gó mez \& Fernández-López 2006). C, uppermost part of Gracilis Biozone (Lower Callovian) at Ricla (after Ramajo \& Aurell 2008). D, Aalenian-Bajocian succession at Tivenys (after Fernández-López et al. 1998). E, Transversarium and Bifurcatus biozones (Middle Oxfordian) at Ricla (after Ramajo \& Aurell 2008). F, uppermost part of Transversarium Biozone at Tosos (new).

between the Bradfordensis Zone (Aalenian) and the Propinquans Zone (Bajocian). The biofacies indicate shallow open marine environments and the ammonoid assemblages support the existence of a relatively free dispersal route between this area and open sea waters. Ammonoids are scarce in the bed yielding Linguithyris, and the resedimented elements correspond to the Concavum Zone of the Upper Aalenian (Fernández-López \& Mouterde 1985). Besides L. nepos, Neozeilleria sp. is the only brachiopod species identified in this level.

\section{The Callovian case}

Kubanithyris bifrons (Oppel) has been recorded at the locality of Ricla (Zaragoza province) (Fig. 2B). The sample consists of 28 specimens including both juvenile and adult individuals (Figs 3D-R) from a single wackestone limestone bed (no. 106) within the Gracilis Biozone (Lower Callovian) (Fig. 2C). The brachiopod association in this level includes also Dorsoplicathyris dorsoplicata (Deslongchamps) and Rhychonelloidella spathica (Lamarck).

The Gracilis Biozone in this locality consists of an alternation of black to grey marls and mudstone to wackestone limestones with abundant Bositra 'fi ments', peloids and siliciclastics (Meléndez et al. 2003, 2007; Page et al. 2004; Ramajo \& Aurell 2008). According to Ramajo \& Aurell (2008), these facies have been deposited in proximal but relatively deep areas of the platform with relatively high-energy conditions. 


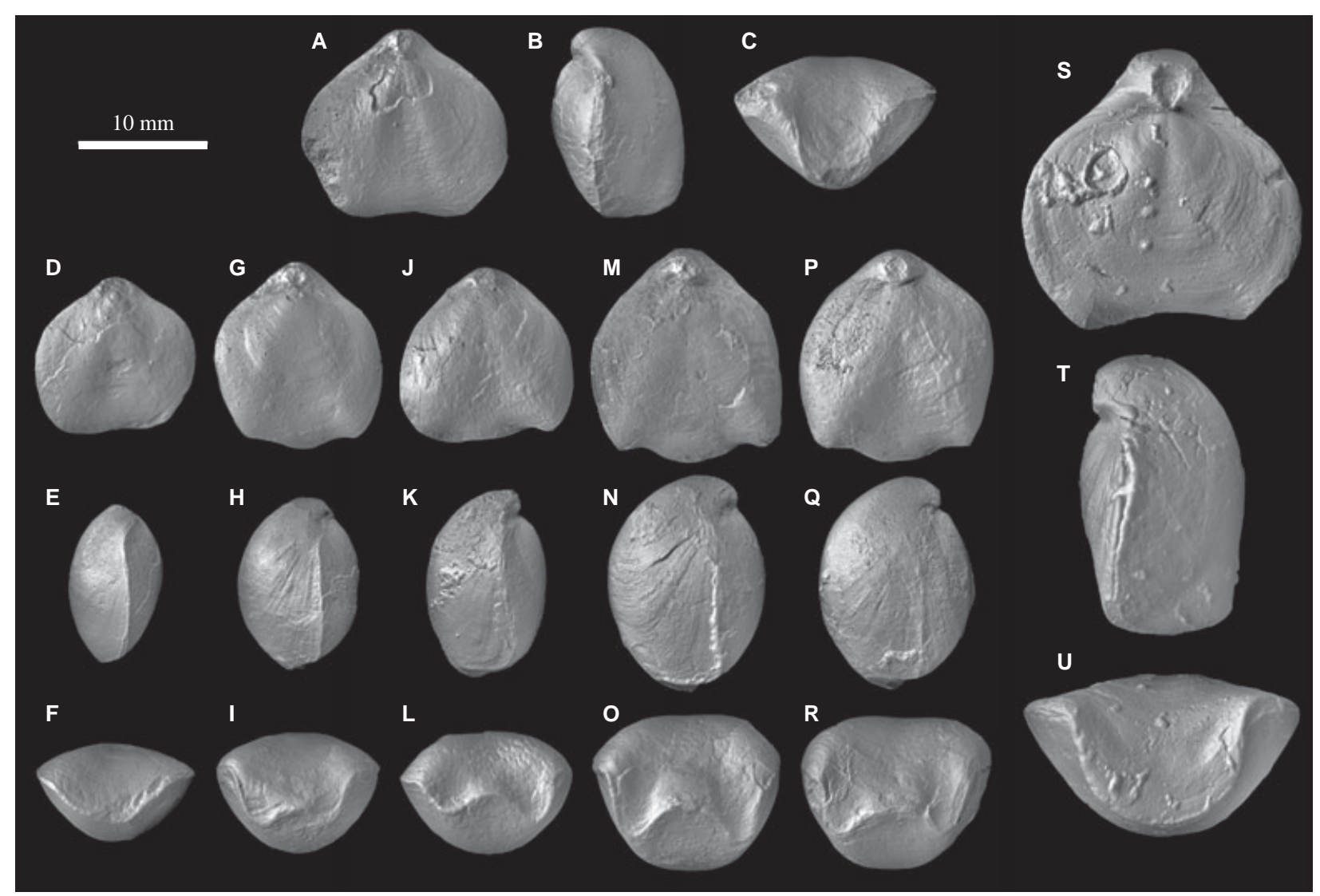

Fig. 3. Nucleatids from the Eastern Iberia platform system (dorsal, lateral and anterior views). All specimens were covered with magnesium. A-C, Linguithyris nepos (Canavari): specimen 9TY128.1, from the Upper Aalenian (Concavum Biozone) of Tivenys (Tarragona Province). D-R, Kubanithyris bifrons (Oppel) from the Lower Callovian (Gracilis Biozone) of Ricla (Zaragoza Province). D-E, juvenile specimen (Ri2/111). G-L, sub-adult specimens. G-I, Ri2/133. J-K, Ri2/124. M-R, adult specimens. M-O, Ri2/119. P-R, Ri2/179. S-U, Nucleata nucleata (Schlotheim): specimen ToA.250/30 from the Middle Oxfordian (Transversarium Biozone) of Tosos (Zaragoza Province).

\section{The Oxfordian case}

Several specimens of Nucleata nucleata (Schlotheim) (Fig. 3S-U) have been recorded in the Middle Oxfordian at the localities of Ricla (Bifurcatus Biozone) and Tosos (Transversarium Biozone) (Fig. 2B). This area of the Aragonese Platform was colonized by siliceous sponges during this interval. Sponges appear either forming metre-thick microbial-sponge mounds or are broken and accumulated, forming graded spongiolithic parasequences, which show an upwardincrease in carbonate content (Page et al. 2004; Ramajo \& Aurell 2008). The development of sponge mounds is considered as indicative of deposition below storm wave base, while spongiolithic facies are interpreted as deposited close to the storm wave base (Ramajo et al. 1999; Ramajo \& Aurell 2008).

N. nucleata occurs in bed no. 50 at the Ricla section (Fig. 2E), which is built up by spongiolithic facies, accompanied by Zeilleria gradata Douvillé, Argovithyris bissuffarcinata (Schlotheim) and Dictyothyris kurri (Oppel). At the Tosos section it occurs in level no. 244, a microbial-sponge mound and in level no. 250, which shows spongiolithic facies (Fig. 2F). It is accompanied by Lacunosella trilobataeformis Wiśniewska, Z. gradata, Argovithyris birmensdorfensis (Moesch), Argovithyris baugieri (d'Orbigny), Moeschia alata (Rollet) and D. kurri in the sponge-mound and by Zittelina orbis (Quenstedt), A. baugieri, M. alata, Z. gradata and Monticlarella strioplanata (Quenstedt) in the spongiolithic facies.

\section{Comparison between the cases}

A clear morphological difference exists between these occurrences of nucleatids at epicontinental environments. L. nepos (Aalenian case) shows the typical bifid (bilobated and laterally expanded) morphology while K. bifrons and N. nucleata (Callovian and Oxfordian cases) show a rather stout and not bilobate morphology. According to the functional interpretations discussed above, L. nepos seems more adapted to epioceanic conditions while the morphology shown by $K$. bifrons and $N$. nucleata could represent an adaptive response to epicontinental conditions as will be discussed in the following paragraphs. This 
hypothesis is supported by the different kinds of assemblages in which they are recorded. The Aalenian case corresponds to a single specimen found isolated at open marine facies. It could be interpreted as punctual arrival across a sweepstake route like those alleged by several authors cited in the introduction of this article. However, in the Callovian and Oxfordian cases they are found associated to populations of Northwestern European taxa, in facies interpreted as indicative of typical epicontinental environments. Consequently, K. bifrons and N. nucleata should be considered as permanent inhabitants of these environments.

\section{Relation between morphology and environment}

In the previous paragraph it has been hypothesized that, according to the theoretical morphofunctional framework previously proposed for the Nucleatidae by several authors, the rather stout and not bilobate morphology of K. bifrons and N. nucleata may indicate their adaptation to epicontinental conditions, enabling lasting settlement at these environments. To test this hypothesis, the morphology of Jurassic nucleatids from different localities and supposedly from different palaeoenvironments was compared.

\section{Methods}

For the description of the nucleatid morphology, three morphological variables with supposed functional significance according to the interpretations from previous authors were selected. First, the lateral expansion of the shell (related with the space available to lodge the lateral arms of the lophophore and with the area exposed when valves gape) is expressed by the difference between the widths of the sides (W in Fig. 4) and that of the median sulcus (S). Second, the horizontal separation of inhalant and exhalant currents is expressed by the absolute value of the difference between the lengths of the median lobe of the shell $\left(\mathrm{L}_{1}\right)$ and that of the lateral lobes $\left(\mathrm{L}_{2}\right)$. Third, the vertical separation of currents is expressed by the sulcus height $(\mathrm{H})$. Measurements were taken from photographs of specimens $\mathrm{fi}$ in the literature and from specimens figured in this article (Figs 3, 5). An optimized random selection of specimens was performed after an exhaustive literature search: all the genera belonging to Nucleatidae but not all species described in individual genera were included in the analysis (type species whenever possible), and restricted to well-illustrated material (Table 1). Four genera were assigned to this family in the revision performed by Lee (2006): Nucleata Quenstedt, Linguithyris Buckman, Kubanithyris Tchorszhevsky and Phymatothyris Cooper and Muir-Wood. Although Buckmanithyris Tchorszhevsky and Carinatothyris Tchorszhevsky were attributed to an uncertain family among the Dyscolioidea by Lee et al. (2007), they were included in the analysis following the opinion of Vörös (2009), who includes them within the Nucleatidae. Likewise, Vjalovithyris Tchorszhevsky, considered a synonym of Nucleata by Manceñido (1993) and Lee (2006), was also included in the analysis because the type species (Terebratula rupicola Zittel and Terebratulites nucleatus Schlotheim) show clear differences both in lateral expansion of their shells and in their environmental/palaeogeographical distribution.

The categorization of taxa to palaeoenvironments is difficult because the literature reports commonly lack sedimentological or palaeoenvironmental information. As previously explained, the main differences between Mediterranean and 'circum-Mediterranean' domains are probably terrigenous input and nutrient availability, factors that also differ between epioceanic and epicontinental environments. Therefore, the reported record at Mediterranean or 'circum-Mediterranean' domains of each taxon has been used herein as an indicator for taxa palaeoenvironmental distribution. According to this criterion Phymatothyris, Linguithyris, Carinatothyris, Buckmanithyris and Vjalovithyris were considered as typical epioceanic nucleatids, while Kubanithyris and Nucleata were considered as typical epicontinental taxa.

Principal components analysis (PCA) has been used as an exploratory method for variable reduction (Hammer \& Harper 2006), simplifying the visualization of the function-related morphological variability within the group and its comparison with taxa palaeoenvironmental distribution. PCA was run using the
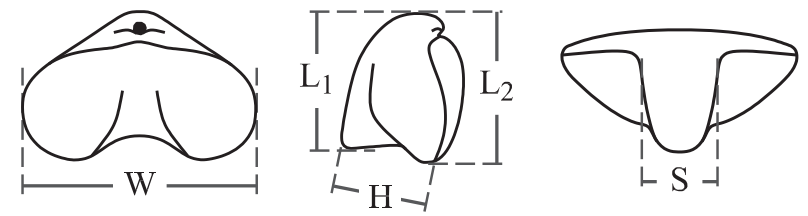

Fig. 4. Measured dimensions; $\mathrm{W}=$ maximum width, $\mathrm{L}_{1}=$ length of median lobe, $\mathrm{L}_{2}=$ length of lateral lobes, $\mathrm{S}=$ width of sulcus, $\mathrm{H}=$ height of sulcus. 
Table 1. Taxa represented in the analysis, selected specimens and their measurements (holotypes are indicated by asterisks).

\begin{tabular}{|c|c|c|c|c|c|c|c|c|}
\hline & Taxon & & Measured specimen & $\mathrm{L}_{1}$ & $\mathrm{~L}_{2}$ & W & S & $\mathrm{H}$ \\
\hline$[P k]$ & Ph. Kerkyraea (Renz) & [1] & Lee(2006) figs 1423, 3 a-c & 25.72 & 27.38 & 27.68 & 17.64 & 11.59 \\
\hline$[C c]$ & C. carinata (Haas) & [2] & Lee et al. (2007) figs $1879,1 \mathrm{a}-\mathrm{c}(*)$ & 14.06 & 18.03 & 24.94 & 11.29 & 11.04 \\
\hline$[B d]$ & B. dziruliensis Tchorszhevsky & [3] & Tchorszhevsky (1990) Pl. 1, figs 4a-c (*) & 13.59 & 14.75 & 18.23 & 9.69 & 5.74 \\
\hline$[L a]$ & L. aspasia (Meneghini) & [4] & Vörös (2009) Pl. XXIV, figs 9 a-c & 12.4 & 16.66 & 25.44 & 9.94 & 9.62 \\
\hline [La] & L. aspasia (Meneghini) & [5] & Vörös (2009) Pl. XXV, figs 6 a-c & 9.14 & 10.36 & 16.28 & 8.24 & 6.96 \\
\hline [La] & L. aspasia (Meneghini) & [6] & Vörös (2009) Pl. XXV, figs 8 a-c & 9.07 & 10.46 & 15.3 & 7.32 & 5.99 \\
\hline$[\mathrm{La}]$ & L. aspasia (Meneghini) & [7] & Herein Figs 5A-C & 10.42 & 12.81 & 19.39 & 7.44 & 8.13 \\
\hline$[\mathrm{Ln}]$ & L. nepos (Canavari) & [8] & $\begin{array}{l}\text { Parona \& Canavari (1882) } \\
\text { Pl. X, figs 1a-d }(*)\end{array}$ & 7.68 & 9.01 & 12.69 & 5.09 & 4.87 \\
\hline$[L n]$ & L. nepos (Canavari) & [9] & $\begin{array}{l}\text { Ferrari \& Manara (1972) } \\
\text { Pl. XXX, figs 2a-d }\end{array}$ & 8.39 & 10.05 & 12.28 & 5.57 & 4.54 \\
\hline$[\mathrm{Ln}]$ & L. nepos (Canavari) & [10] & Herein Figs 3A-C & 11.5 & 12.43 & 13.55 & 7.15 & 5.43 \\
\hline$[\mathrm{Lb}]$ & L. bifida (Rothpletz) & [11] & Vörös (1995) Pl. I, figs 7a-c & 14.81 & 17.17 & 20.12 & 8.36 & 7.54 \\
\hline$[L b]$ & L. bifida (Rothpletz) & [12] & Herein Figs 5D-F $(*)$ & 14.77 & 17.51 & 22.75 & 12.83 & 8.45 \\
\hline$[K p]$ & K. parvus Tchorszhevsky & [13] & $\begin{array}{l}\text { Tchorszhevsky (1989) } \\
\text { Pl. II, figs 5a-c }(*)\end{array}$ & 10.99 & 10.18 & 12.09 & 6.23 & 6.04 \\
\hline$[\mathrm{Km}]$ & $\begin{array}{l}\text { K. mitrovici (Tchorszhevsky } \\
\text { \& Radulović) }\end{array}$ & [14] & $\begin{array}{l}\text { Tchorszhevsky \& Radulović(1984)Pl. IV, } \\
\text { figs 13-16 }\end{array}$ & 20.09 & 19.59 & 17.01 & 9.02 & 6.54 \\
\hline$[K m]$ & $\begin{array}{l}\text { K. mitrovici (Tchorszhevsky } \\
\text { \& Radulovic) }\end{array}$ & [15] & $\begin{array}{l}\text { Tchorszhevsky \& Radulović(1984) } \\
\text { Pl. IV, figs 17-20(*) }\end{array}$ & 16.49 & 16.45 & 17.46 & 10.65 & 5.74 \\
\hline$[K v]$ & K. vicaria (Szajnocha) & [16] & $\begin{array}{l}\text { Tchorszhevsky \& Radulović(1984) } \\
\text { Pl. IV, figs 9-12 }\end{array}$ & 20.68 & 19.05 & 18.69 & 12.01 & 5.35 \\
\hline$[\mathrm{Kv}]$ & K. vicaria (Szajnocha) & [17] & Atrops \& Alméras (2005) Pl. II, fig. 4 & 13.47 & 12.47 & 12.99 & 12.25 & 4.09 \\
\hline$[K b]$ & K. bifrons (Oppel) & [18] & Atrops \& Alméras (2005) Pl. II, fig. 2 & 16.07 & 14.56 & 15.55 & 13.38 & 4.80 \\
\hline$[K b]$ & K. bifrons (Oppel) & [19] & Herein Figs 3M-O & 14.1 & 13.56 & 12.81 & 10.72 & 2.83 \\
\hline$[K b]$ & K. bifrons (Oppel) & [20] & Herein Figs 3P-R & 13.99 & 13.26 & 12.76 & 10.25 & 2.60 \\
\hline$[K c]$ & K. chartroni (De Grossouvre) & [21] & $\begin{array}{l}\text { De Grossouvre }(1891) \\
\text { Pl. 9, figs 9a-d }(*)\end{array}$ & 13.97 & 13.3 & 13.56 & 11.54 & 4.09 \\
\hline$[\mathrm{Nn}]$ & N. nucleata (Schlotheim) & [22] & Cooper (1983) Pl. 36, figs 7-9 & 15.38 & 16.68 & 16.37 & 9.48 & 6.61 \\
\hline$[\mathrm{Nn}]$ & N. nucleata (Schlotheim) & [23] & Herein Figs 3S-U & 16.75 & 17.8 & 18.53 & 11.75 & 7.71 \\
\hline$[\mathrm{Vb}]$ & V. bouei (Zeuchner) & [24] & Geyssant (1966) Pl. 1, figs 4a-d & 19.9 & 21.91 & 21.24 & 13.67 & 9.06 \\
\hline$[\mathrm{Vb}]$ & V. bouei (Zeuchner) & [25] & Herein Figs 5G-I & 13.15 & 17.52 & 23.14 & 11.28 & 11.41 \\
\hline$[V r]$ & V. rupicola (Zittel) & [26] & Geyssant (1966) Pl. 1, figs 6a-d & 14.94 & 18.57 & 26.78 & 9.79 & 10.90 \\
\hline$[V r]$ & V. rupicola (Zittel) & [27] & Sequeiros (1977) figs 3, 2a-c & 12.02 & 17.87 & 23.73 & 8.36 & 11.75 \\
\hline
\end{tabular}

variance-covariance matrix of log-transformed measurements. The differentiation between epioceanic and epıcontınental nucleatıds was tested using discriminant analysis (DA). Both analyses were carried out using the PAST package (Hammer et al. 2001).

\section{Results}

The two-fi components obtained by the PCA (PC1 and PC2) explain $97 \%$ of the variance within the data (Table 2), and have accordingly been considered as representing the variability within the group. Specimens appear relatively clustered along PC1 according to their provenance (higher values for epioceanic taxa), although both groups partially overlap (Fig. 6). This distribution does not seem to be completely sizerelated because PC1 and size (expressed as maximum length of the shell, $\mathrm{L}_{1}$ or $\mathrm{L}_{2}$ ) show a low value of correlation $(r=0.275)$ and size difference between both groups is not significant (Mann-Whitney test reports a probability of $p=0.981$ for equality of the medians). However, the specimens at the overlapping area correspond to large epicontinental taxa ( $N$. nucleata,
Table 2. Compilation of principal components analysis and discriminant analysis results.

\begin{tabular}{|c|c|c|c|c|c|c|c|}
\hline & \multirow{2}{*}{$\begin{array}{l}\text { Eigen } \\
\text { value }\end{array}$} & \multirow{2}{*}{$\begin{array}{l}\text { Percentage } \\
\text { variance }\end{array}$} & & \multicolumn{3}{|c|}{ Loadings } & \multirow{2}{*}{$\begin{array}{l}\text { Discriminant } \\
\text { coefficient }\end{array}$} \\
\hline & & & & PC1 & PC2 & PC3 & \\
\hline PC1 & 0.23 & 73.20 & VS & 0.28 & 0.30 & 0.91 & 0.19 \\
\hline PC2 & 0.07 & 24.02 & HS & 0.81 & 0.58 & 0.06 & 0.27 \\
\hline PC3 & 0.01 & 2.78 & LE & 0.51 & 0.76 & 0.41 & 0.66 \\
\hline
\end{tabular}

Abbreviations: VS: vertical separation of currents; HS: horizontal separation of currents; LE: lateral expansion of the shell.

K. vicaria) and small epioceanic taxa (L. aspasia, L. nepos). The loading values obtained for PC1 (Table 2 and Fig. 6) indicate that epioceanic taxa show greater current separation (mainly at the horizontal component, loading 0.81) and lateral expansion (with a 0.51 loading). PC2 values correlate with the difference between horizontal separation of currents ()0.58 loading) and both lateral expansion of the shell (0.76 loading) and vertical separation of currents (0.3 loading). Due to the great current separation and lateral expansion shown by epioceanic taxa, their values for PC2 are always small and close to 0. Contrarily, 


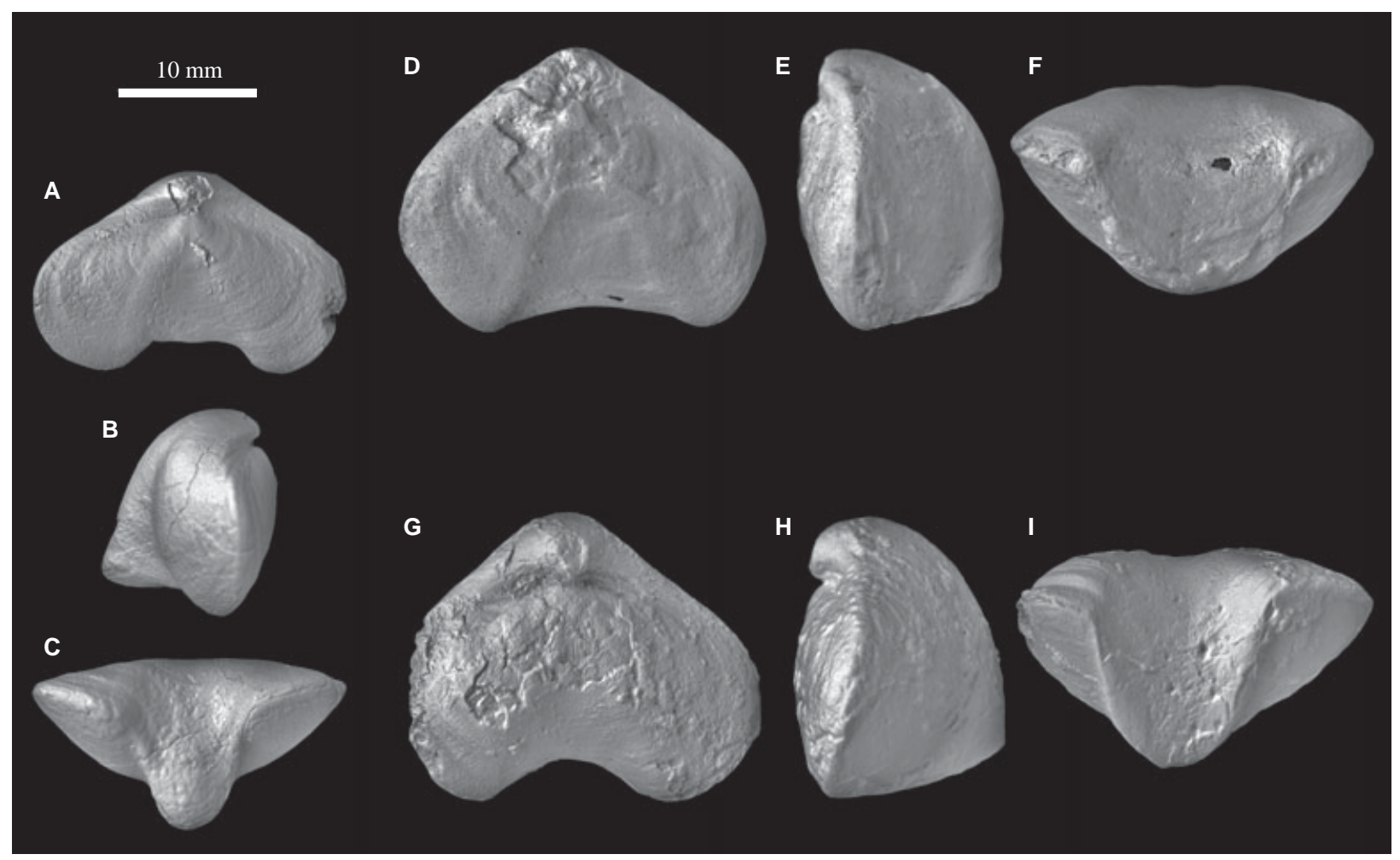

Fig. 5. Specimens of nucleatids coming from out of the Eastern Iberia platform system included in the morphofunctional analysis (dorsal, lateral and anterior views). All specimens were covered with magnesium. A-C, Linguithyris aspasia (Meneghini): specimen LaHu.1 from the Upper Pliensbachian of the Bakony Mountains (Hungary). D-F, Linguithyris bifida (Rothpletz), plaster cast of holotype specimen (BSP/NT.ASXXIV/242 figured by Rothpletz 1886, Pl. V, fig. 17) from Middle Jurassic of Rothen Stein (Vils Alps, Austria). G-I, Vjalovithyris bouei (Zeuchner): specimen KE1/9/2 from the Upper Oxfordian (Bimammatum Biozone) of Estepa (Sevilla Province, Spain).

epicontinental taxa show a wider distribution of values for PC2, which indicates that the proportions between the variables vary widely within these taxa.

Similar results have been obtained from the DA. Although the percentage of specimens correctly assigned according to their palaeoenvironmental setting is not extremely high (89\%), there is a noticeable separation between epicontinental and epioceanic taxa (Fig. 7). The discriminant function coefficients for each variable (Table 2) indicate, as loadings on PC1 do, that this differentiation is due to the greater lateral expansion of the shell and horizontal separation of currents in epioceanic taxa. The incorrectly assigned specimens are two L. nepos (9 and 10 at Table 1 , whose scores are 0.17 and )0.76, respectively) and one $V$. bouei (24 at Table 1, which score is )0.39) with relatively small lateral expansion of the shell. The variation in discriminant scores through time (Fig. 8) has been used to visualize the temporal changes in the morphology of nucleatids. The higher scores (higher epioceanic character) are reached by L. aspasia and $V$. rupicola during Early and Late Jurassic, respectively, while the lower ones (lower epicontinental character) are reached by $K$. vicaria, K. chartroni and $K$. bifrons at the end of the Middle Jurassic.

\section{Discussion}

The results of both analyses agree with the hypothesis that the variation in the morphological variables with alleged functional significance between nucleatid taxa is related with their palaeobiogeographical distribution (and therefore, palaeoenvironmental setting). Nucleatids at epicontinental environments tend generally to display less laterally expanded shells and smaller current separation (mainly its horizontal component) than nucleatids at epioceanic environments do. This deviation from the typical nucleatid morphology displayed by epicontinental taxa can be interpreted in functional terms according to the model previously explained. Less laterally expanded shells accommodate smaller lophophore lateral arms (Fig. 1) leading to lesser nutrient-fi effi iency. This apparent disadvantage in filtration effi ncy seems less important at epicontinental, nutrient-rich environments, and it is countered by an increased protection against harmful particles. Siliciclastic input is higher at epicontinental environments due to their proximity to emerged areas and less laterally expanded shells have shorter commissures, exposing a reduced area when valves gape. It 


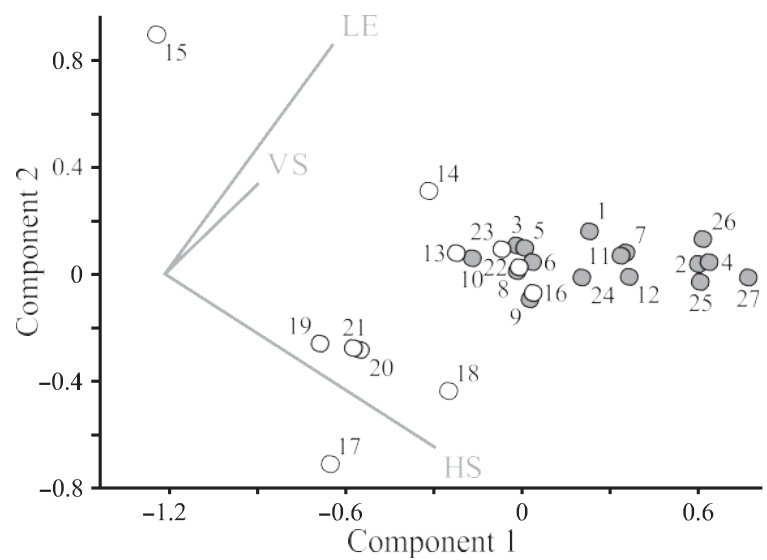

Fig. 6. Biplot of scores and loadings on PC1 and PC2 (empty circles: taxa mainly restricted to epicontinental environments; filled circles: taxa mainly restricted to epioceanic environments; for number-key to specimens, see Table 1; VS: vertical separation of currents; HS: horizontal separation of currents; LE: lateral expansion of the shell).

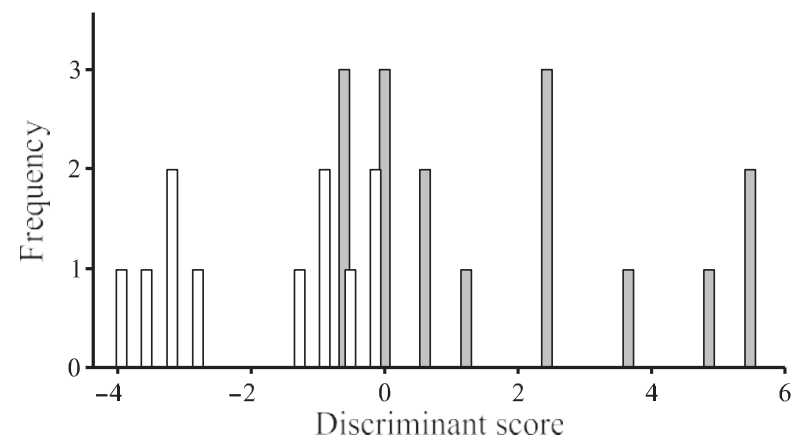

Fig. 7. Histogram of discriminant scores (empty bars: taxa mainly restricted to epicontinental environments; filled bars: taxa mainly restricted to epioceanic environments).

is noteworthy that the $L$. nepos specimen reported herein from epicontinental settings (Figs 3A-C; 10 at Table 1) exhibits the most negative (epicontinental) discriminant score among the epioceanic taxa, probably due to an ecophenotypic change. According to the classic scheme by Rudwick (1964), the intraplicate anterior commissure displayed by Kubanithyris species would enhance protection against particles, because deflexion in commissure permits to reduce the separation between the valves keeping the same area for water exchange (Fig. 1). By this means, the maximum size of admitted particles is reduced.

The variation of the morphological differentiation between epioceanic and epicontinental nucleatids (discriminant scores) through time points out several noteworthy aspects (Fig. 8). A clear epioceanic character (positive discriminant scores) is noticeable during the Early Jurassic, when nucleatids only occur at the Mediterranean domain. Minimum epioceanic and epicontinental-like values are reached during the Middle
Jurassic coinciding with the occasional occurrences of epicontinental taxa in the Northwestern European domain. The higher epicontinental characters (negative discriminant scores) are reached at the end of the Middle Jurassic, when the colonization of the 'circumMediterranean' areas by nucleatids becomes more evident and strict epicontinental species appear (K. bifrons and other intraplicate taxa). The maintenance of this settlement during the Late Jurassic is evidenced by the values displayed by $N$. nucleata, consistent with its record in a variety of environments across the European platform since the Early Oxfordian. This interval (Callovian-Oxfordian) coincides with the widespread occurrence of radiolarites in the Mediterranean domain evidencing deposition below the calcite compensation depth (De Wever 1989). These conditions must have been unfavourable for benthic organisms with carbonate skeleton such as brachiopods, and the Mediterranean region almost devoid of this fauna during this interval (Vörös 2005). An increase in the epioceanic character is observed after this critical episode, coinciding with the occurrence of $V$. bouei and $V$. rupicola at epioceanic environments in the Late Oxfordian. These species display bifi morphology very similar to that of the Lower Jurassic Linguithyris species.

Following these interpretations an hypothesis may be built: while nucleatids became extinct in the Mediterranean domain due to the harsh conditions related with the radiolarian event, 'circum-Mediterranean' populations survived and reoccupied the Mediterranean domain once these conditions disappeared. Nevertheless, alternative hypotheses might explain the absence of nucleatids at the Mediterranean domain, such as reduced preservation rates, absence of deposits (stratigraphic hiatus) or unequal sampling.

\section{Consequences for systematics}

The conservative character of the morphology shown by many species of Nucleatidae has prevented clear differentiation at genus level. Several nominal genera have been erected during the last two centuries but frequently based on weak criteria. Manceñido (1993, p. 194) noted these diffi ulties in the distinction between Linguithyris and Nucleata. Details of the dorsal abductor muscle scars, not always observable, have been considered by this author as the only objective criterion. The stratigraphic position has been implicitly used by several authors to separate these genera: Linguithyris would include the Lower and early Middle Jurassic species while Nucleata would include younger ones (Manceñido 1993; Alméras et al. 2007). Vörös (2009) adds a new criterion: Linguithyris is 


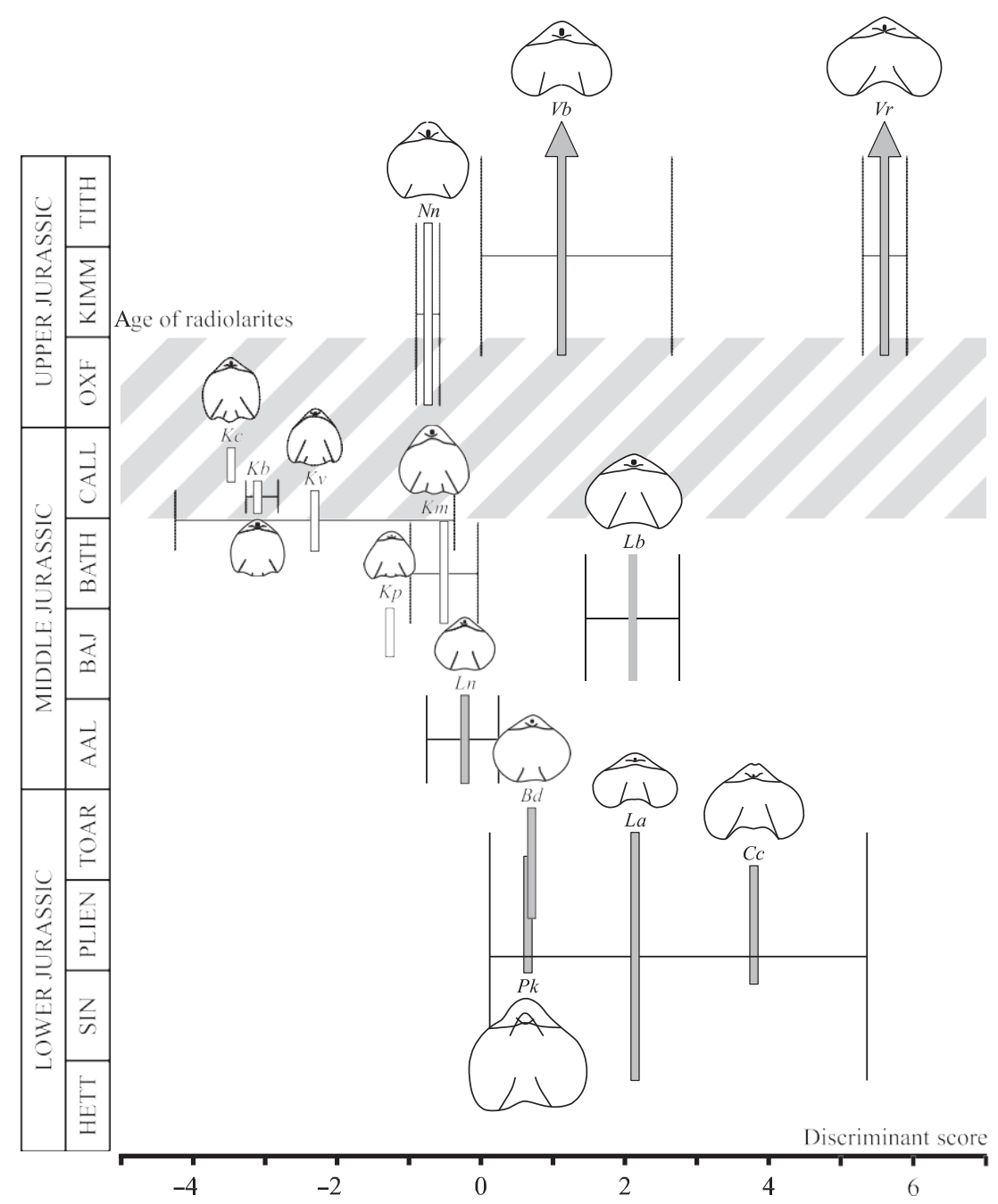

Fig. 8. Temporal variation of nucleatid morphology expressed as the discriminant scores of the studied taxa. Mean, minimal and maximal values are given for taxa represented by more than one specimen (same legend as Fig. 7; for taxa abbreviations, see Table 1). Specimens drawn to scale $(\cdot 0.75)$.

characterized by its bifi shell while Nucleata presents a rather stout and globose shape. The generic attribution of the group of intraplicate forms that occur at the end of the Middle Jurassic is the kernel of this problem. The species included in this group are Terebratula bifrons Oppel, Terebratula vicaria Szajnocha, Terebratula tenuiplicata Uhlig, Terebratula chartroni De Grossouvre and Nucleata mitrovici Tchorszhevsky and Radulović. Some of them have been recently assigned both to Linguithyris (Tchorszhevsky 1989; Radulović \& Rabrenović 1993; Atrops \& Alméras 2005) and Nucleata (Tchorszhevsky \& Radulović 1984).

A more justifiable systematic arrangement emerges from the interpretation of the observed adaptive changes and their temporal evolution, considering taxa as evolutive units. According to this:
1. The Lower and Middle Jurassic species with bifi morphology, mainly restricted to epioceanic environments (= Mediterranean Province), should be grouped in the genus Linguithyris Buckman. Detailed analysis of intra- and interspecifi variation in species belonging to Buckmanithyris Tchorszhevsky and Carinatothyris Tchorszhevsky are needed to verify whether these genera are actually different from Linguithyris. The validity of Phymatothyris Cooper and Muir-Wood is justified by its free-lying mode of life and the related morphological modifications (see p. 195 in Manceñido 1993).

2. The adaptation to epicontinental environments during the late Middle Jurassic leads to the differentiation of a group of nominal species ( $T$. bifrons Oppel, T. vicaria Szajnocha, T. tenuiplicata Uhlig, 
T. chartroni De Grossouvre, N. mitrovici Tchorszhevsky and Radulović), which share stout morphology and intraplicate commissure. They should be assigned to Kubanithyris Tchorszhevsky because intraplication is already present in the type species, K. parvus Tchorszhevsky.

3. The genus Nucleata Quenstedt should be restricted to the early Upper Jurassic stout but not intraplicate forms that became ubiquitous at the epicontinental areas of the Tethyan margins, since this is the precedence of its type species, Terebratulites nucleatus Schlotheim.

4. The species that occur at epioceanic environments since Upper Jurassic showing bifi morphology quite similar to that displayed by the Lower Jurassic Linguithyris should belong to a genus different from Nucleata, to which they are commonly assigned. The absence of fossil record with bifid forms in epioceanic domains during the 'age of radiolarites' precludes a direct phylogenetic relation of these species with Linguithyris despite the strong morphological similarity.

Tchorszhevsky (1989) erected the genus Vjalovithyris on the basis of one of these species, Terebratula rupicola Zittel, and thus, Vjalovithyris should be used to name this group.

\section{Conclusions}

The analysis of Jurassic nucleatids shows that their morphology is related with their palaeobiogeographical and palaeoenvironmental distribution. The differentiation between the epioceanic (Mediterranean) and the epicontinental (Northwestern European and North African) taxa is mainly apparent in the lateral expansion of the shell. The reduction in the lateral expansion of the shell displayed by epicontinental forms involves a shortening of the commissure, which is interpreted as a protection mechanism against harmful particles, most abundant in epicontinental environments. The intraplication of the anterior commissure developed in some of these forms would be a further step in the protection by increasing the particle sieving.

A new systematic arrangement for Jurassic Nucleatidae is proposed based on the temporal evolution of the morphological adaptations. Accordingly, Linguithyris Buckman should be restricted to the Lower and Middle Jurassic species with bifid shape; Kubanithyris Tchorszhevsky groups the species from the late Middle Jurassic with stout morphology and intraplicate sinus; Nucleata is limited to the unisulcate species that are ubiquitous in the epicontinental domains from the Upper Jurassic; and finally, Vjalovithyris Tchorszhevsky would include the bifi species from the Upper Jurassic.

Acknowledgements. - This study is a contribution to the projects CGL2008-01273/BTE (JC and FGJ) and CGL2008-03112 (FGJ) of MICINN, to the project GR58/08B/919431 (FGJ) of UCM, and to the Grupo Consolidado E-17 of the Gobierno de Aragó n (JC). Financial support has also been provided by an FPU grant AP2007-03856 (JC) of MICINN and by the Dirección General de Patrimonio Cultural de Aragón (Exp. 092/2009). We owe special thanks to Prof. L. Sequeiros for giving permission to use and figure his material deposited at the University of Zaragoza. Finally, authors are deeply grateful to A. Tomašových and another anonymous reviewer for helpful comments that have undoubtedly improved this work.

\section{References}

Ager, D.V. 1959: Lower Jurassic brachiopods from Turkey. Journal of Paleontology 33, 1018-1028.

Ager, D.V. 1960: Brachiopod distributions in the European Mesozoic. Report of the International Geological Congress, XXI Session, Norden, 1960, part XXII, 20-25.

Ager, D.V. 1965: The adaptation of Mesozoic brachiopods to different environments. Palaeogeography, Palaeoclimatology, Palaeoecology 1, 143-172.

Ager, D.V. 1967: Some Mesozoic brachiopods in the Tethys region. in Adams C.G., Ager, D.V. (eds): Aspects of Tethyan Biogeography. Sistematysts Association Publication 7, 135-151. The Sistematysts Association, London.

Ager, D.V. 1971: Space and time in brachiopod history. In Middlemiss, F.A., Rawson, P.F., Newall, G. (eds): Faunal Provinces in Space and Time; Geological Journal Special Issue 4, 95-110. Seel House Press, Liverpool.

Ager, D.V. 1973: Mesozoic Brachiopoda. In Hallam. A. (ed.): Atlas of Palaeobiogeography, 431-436. Elsevier Scientific Publishing Company, Amsterdam.

Ager, D.V. 1986: Migrating fossils, moving plates and expanding earth. Modern Geology 10,377-390.

Ager, D.V. 1993: Mesozoic brachiopods and seamounts. In Pálfy, J., Vörös, A. (eds): Mesozoic Brachiopods of Alpine Europe, 11-13. Hungarian Geological Society, Budapest.

Ager, D.V. \& Sun, D.L. 1989: Distribution of Mesozoic brachiopods on the northern and southern shores of Tethys. Palaeontologia Cathayana 4, 23-51.

Ager, D.V. \& Walley, C.D. 1977: Mesozoic brachiopod migrations and the opening of the North Atlantic. Palaeogeography, Palaeoclimatology, Palaeoecology 21, 85-99.

Alméras, Y., Elmi, S. \& Fauré, P. 2007: Les Brachiopodes Liasiques d'Algérie occidentale. Documents des Laboratoires de Géologie Lyon 163, 1-241.

Atrops, F. \& Alméras, Y. 2005: Les Brachiopodes du Callovien de l’Ouarsenis (Tell algérien): paléontologie, biostratigraphie et paléoenvironnements. Revue de Paléobiologie, Genève 24, 563595.

Aurell, M., Meléndez, G. \& Bádenas, B. 2002: East Iberian basins. In Gibbons, W., Moreno, T. (eds): The Geology of Spain, 223235. Geological Society, London.

Baeza-Carratalá, J.F. 2004: Revisión de la fauna de braquió podos del Jurásico Inferior en el Cerro de La Cruz (La Romana, Alicante). Resultados preliminares. Geo-Temas 7, 209-212.

Baeza-Carratalá, J.F., 2008: Patrimonio paleontológico en la colección Jiménez de Cisneros y su aplicación al estudio de los braquiópodos del Jurásico Inferior en la Cordillera Bética Oriental (provincias de Alicante y Norte de Murcia). Unpublished Doctoral Thesis, Universidad de Alicante, 906 pp.

Buckman, S.S. 1906: Brachiopod Homoeomorphy: Pygope, Antinomia, Pygites. Quarterly Journal of the Geological Society of London 62, 433-455. 
Choffat, P. 1947: Description de la faune jurassique du Portugal. Brachiopodes, 46 pp. Serviçio Geologico de Portugal, Lisbon.

Cooper, G.A. 1972: Homoeomorphy in Recent deep-sea brachiopods. Smithsonian Contributions to Paleobiology11,1-25.

Cooper, G.A. 1983: The Terebratulacea (Brachiopoda), triassic to recent: a study of the brachidia (loop). Smithsonian Contributions to Paleobiology 50,1-445.

De Grossouvre, M.A. 1891: Sur le Callovien de l’Ouest de la France et sur sa faune. Bulletin de la Société Géologique de France, 3eme série 19, 247-262.

De Wever, P. 1989: Radiolarians, Radiolarites and Mesozoic Paleogeography of the Circum-Mediterranean Alpine Belts. In Hein J.R.\& Obradovic J. (eds): Siliceous deposits of the Tethys and Pacific Regions,31-49. Springer-Verlag, New York.

Dubar, G. 1931: Lias et jurassique du Baztan (Haute Vallée de la Bidassoa - Espagne). Bulletin de la Société géologique de France, Série 430,589-608.

Emig, C.C. 1992: Functional disposition of the lophophore in living Brachiopoda. Lethaia 25, 291-302.

Fernández-López, S. \& Mouterde, R. 1985: Le Toarcien, l’Aalénien et le Bajocien dans le secteur de Tivenys: nouvelles données biostratigraphiques. Strata 2, 71-82.

Fernández-López, S., Aurell, M., García Joral, F., Gómez, J.J., Henriques, M.H.P., Meléndez, G. \& Suárez Vega, L.C. 1996: El Jurásico Medio de la Cuenca Catalana: unidades litoestratigráficas y elementos paleogeográficos. Revista Española de Paleontología Special Issue, 122-139.

Fernández-López, S., García Joral, F., Gómez, J.J., Henriques, M.H.P. \& Martínez, G. 1998: La diferenciación paleogeográfi de la Cuenca Catalana al principio del Jurásico Medio. Revista de la Sociedad Geológica de España 11, 3-22.

Fernández-Ló pez, S., Aurell, M., García Joral, F., Gó mez, J.J. Henriques, M.H.P., Martínez, G., Meléndez, G. \& Suárez Vega, L.C. 1999: La Plataforma de Tortosa (Cuenca Catalana) durante el Jurásico Medio: unidades litoestratigráficas, paleogeografía y ciclos ambientales. Cuadernos de Geología Ibérica 24, 185221.

Ferrari, A. \& Manara, C. 1972: Brachiopodi del Dogger inferiore di Monte Peller - Trentino. Giornale di Geología, Annali del Museo Geologico di Bologna (serie 2) 38, 253-348.

Geyssant, J. 1966: Etude paléontologique des faunes du Jurassique supérieur de la zone prérifaine du Moyen Ouerrha. Première partie: Glossothyris et Pygope (Terebratulidae) Essai de répartition de ces espèces dans le domaine Méditerranéen. Notes des Services Géologiques du Maroc 26, 75-103.

Gó mez, J.J. \& Fernández-López, S.R. 2004: Primera fase de postrifting: Jurásico Medio. In Vera, J.A. (ed.): Geología de España, 500-503. Sociedad Geológica de España and Instituto Geológico y Minero de España, Madrid.

Gó mez, J.J. \& Fernández-Ló pez, S.R. 2006: The Iberian Middle Jurassic carbonate-platform system: Synthesis of the palaeogeographic elements of its eastern margin (Spain). Palaeogeography, Palaeoclimatolooy, Palaeoecolooy 236, 190-205.

Hallam, A. 1971: Provinciality in Jurassic faunas in relation to facies and palaeogeography. In Middlemiss, F.A., Rawson, P.F.\& Newall, G. (eds): Faunal Provinces in Space and Time; Geological Journal Special Issue 4, 129-152. Seel House Press, Liverpool.

Hammer, Ø. \& Harper, D.A.T. 2006: Paleontological data analysis, 351 pp. Blackwell Publishing, Oxford.

Hammer, Ø., Harper, D.A.T. \& Ryan, P.D. 2001: PAST: Palaeontological Statistics software package for education and data analysis.PalaeontologiaElectronica 4,9 .

Harper, D.A.T., Alsen, P., Owen, E.F. \& Sandy, M.R. 2005: Early Cretaceous brachiopods from North-East Greenland: Biofacies and Biogeography. Bulletin of the Geological Society of Denmark $52,213-225$.

Jiménez de Cisneros, D. 1923: La fauna de los estratos de 'Pygope aspasia' Menegh. del Liásico medio del Rincón de Egea, en el NW de la provincia de Murcia. Trabajos del Museo Nacional de Ciencias Naturales, Serie Geológica30,1-55.

Jiménez de Cisneros, D. 1935: La Fauna Liásica de los Cerros de Ayala y de la Cruz de la Algueña en la parte occidental de la provincia de Alicante. Memorias de la Sociedad Ibérica de Ciencias Naturales 7,1-31.

LaBarbera, M. 1981: Water flow patterns in and around three species of articulate brachiopods. Journal of Experimental Marine Biology and Ecology 55, 185-206.

Lee, D.E. 2006: Dyscolioidea. In Williams, A. et al. (eds): Treatise on Invertebrate Paleontology, part $\mathrm{H}$, Brachiopoda (Revised), Volume 5, 2136-2144. The Geological Society of America and The University of Kansas, Boulder and Lawrence.

Lee, D.E., MacKinnon, D.I. \& Smirnova, T.N. 2007: Terebratulidina. In Williams, A. et al. (eds): Treatise on Invertebrate Paleontology, Part H, Brachiopoda (Revised) Volume 6, 2801-2816. The Geological Society of America and The University of Kansas, Boulder and Lawrence.

Manceñido, M.O. 1993: First record of Jurassic nucleatid brachiopods from the southwest Pacific with comments on the global distribution of the group. Palaeogeography, Palaeoclimatology, Palaeoecology 100, 189-207.

Manceñido, M.O. 2002: Paleobiogeography of Mesozoic brachiopod faunas from Andean-Patagonian areas in a global context. Geobios35,176-192.

Martín-Algarra, A. \& Vera, J.A. 2004: La Cordillera Bética y las Baleares en el contexto del Mediterráneo Occidental. In Vera, J.A. (ed.): Geología de España, 352-354. Sociedad Geológica de España and Instituto Geoló gico y Minero de España, Madrid.

Meléndez, G., Ziani, H., Ramajo, J. \& Bello, J. 2003: Le Callovien et la limite Callovien-Oxfordien dans les secteurs central et oriental de la plate-forme aragonaise (NE Ibérie, Espagne). Notes et Mémoires Services Géologiques du Maroc 452, 91-98.

Meléndez, G., Ramajo, J., Bello, J. \& Page, K.N. 2007: Callovian and the Callovian-Oxfordian transition sedimentary record in NE Iberian Chain. Taphonomic analysis and palaeogeography. JournalofIberian Geology33,261-282.

Olóriz, F. 2000: Time-averaging and long-term palaeoecology in macroinvertebrate fossil assemblages with ammonites (Upper Jurassic). Revue de Paléobiologie, Genèvevol. spéc. 8,123-140.

Owen, E.F. 1976: Some Lower Cretaceous brachiopods from East Greenland. Meddelelser om Grønland 171,1-19.

Page, K.N., Bello, J., Lardiés, M.D., Meléndez, G., Ramajo, J. \& Ziani, H. 2004: The stratigraphy of the Upper Bathonian to Middle Oxfordian succession of the Aragonese branch of the Cordillera Ibérica (Spain) and its European context. Rivista Italiana di Paleontologia e Stratigrafia 110,191-200.

Parona, C.F. \& Canavari, M. 1882: Brachiopodi oolitici di alcune localitá dell'Italia Settentrionale. Atti della Società Toscana di Scienze Naturali 5, 331-350.

Radulović, V. \& Rabrenović, D. 1993: Brachiopods from the 'Klaus Beds' of the Yugoslavian Carpatho-Balkanides. In Pálfy, J. \& Vörös, A. (eds): Mesozoic Brachiopods of Alpine Europe, 113-126. Hungarian Geological Society, Budapest.

Ramajo, J. \& Aurell, M. 2008: Long-term Callovian-Oxfordian sea-level changes and sedimentation in the Iberian carbonate platform (Jurassic, Spain): possible eustatic implications. Basin Research 20, 163-184.

Ramajo, J., Aurell, M., Bádenas, B., Bello, J., Delvene, G., Meléndez G. \& Pérez-Urresti, I. 1999: Síntesis del Oxfordiense en la Cuenca Ibérica Nororiental y correlación con la Cuenca Catalana. Cuadernos de Geología Ibérica 25, 111-137.

Reolid, M. 2005: Asociaciones de braquió podos del Oxfordiense medio-Kimmeridgiense inferior en la Zona Prebética (Sureste de España): Relación con las litofacies y el gradiente proximal-distal de la plataforma. Revista Española de Paleontología 20, 21-36.

Rothpletz, A. 1886: Geologisch-palaeontologische Monographie der Vilser Alpen, mit besonderer Berücksichtigung der Brachiopoden-Systematik. Palaeontographica 33, 1-180.

Rudwick, M.J.S. 1962: Filter-feeding mechanisms in some brachiopods from New Zealand. Journal of the Linnean Society of London, Zoology 44, 592-615.

Rudwick, M.J.S. 1964: The function of zigzag deflexions in the commisures of fossil brachiopods. Palaeontology 7, 135-171.

Rudwick, M.J.S. 1970: Living and Fossil Brachiopods, 199 pp. Hutchinson University Library, London. 
Sequeiros, L. 1977: Nuevos datos paleontológicos y bioestratigráfi s de Glossothyris (Brachiopoda, Terebratulidae) en la Zona Subbética (España meridional). Acta Geológica Hispánica 12, 8-11.

Tchorszhevsky, E.S. 1989: O iurskikh terebratulidakh Nucleatidae (Brakhiopody) [Jurassic Terebratuloid Nucleatidae Brachiopoda]. Paleontolooicheskii Zhurnal4,25-36.

Tchorszhevsky, E.S. 1990: K sistematike iurskikh sil'katnykh Terebratulida (Brachiopoda) [On systematics of Jurassic sulcate Terebratulida].Paleontologicheskii Sbornik27,31-39.

Tchorszhevsky, E.S. \& Radulović, V. 1984: Novi podatsi o srednje jurskim terebratulidama (Brachiopoda) Karpata (SSSR) I Karpato-Balkanida (Jugoslavija) [New data of Middle Jurassic terebratulids (Brachiopoda) of the Carpathians (USSR) and Carpatho-Balkanides (Yugoslavia)]. Annales Géologiques de la Péninsule Balkanique 48, 129-184.

Tchoumatchenco, P. 1986: Répartition paléoécologique des brachiopodes jurassiques dans les Monts de Tiaret et l'Ouarsenis occidental (Algérie). In Racheboeuf, P.R.\& Emig, C.C. (eds): Les brachiopods fossiles et actuels. Biostratigraphie du Paleozoïque 4, 389-398. Université de Bretagne Occidentale, Brest.

Vogel, K. 1966: Eine funktiosmorphologische studie an der Brachiopodengattung Pygope (Malm bis Unterkreide). Neues Jahrbuch für Geologie und Paläontologie, Abhandlungen 125, 423-442.

Vörös, A. 1977: Provinciality of the Mediterranean Lower Jurassic brachiopod fauna: causes and plate tectonic implications. Palaeogeography, Palaeoclimatology, Palaeoecology 21, 1-16.
Vörös, A. 1988: Conclusions on Brachiopoda. In Rakus, M., Dercourt, J., Nairn, A.E.M. (eds): Evolution of the Northern Margin of the Tethys. Mémoires de la Sociét Géologique de France, nouvelle série 154,79-83. Société Géologique de France, Paris.

Vörös, A. 1993: Jurassic microplate movements and brachiopod migration in the western part of the Tethys. Palaeogeography, Palaeoclimatology, Palaeoecology 100, 125-145.

Vörös, A. 1995: Bathonian brachiopods of the Mecsek Mts (Hungary). Annales Universitatis Scientiarum Budapestinensis de Rolando Eötvös Nominatae, Sectio geologica 30, 181-208, 237238.

Vörös, A. 2005: The smooth brachiopods of the Mediterranean Jurassic: refugees or invaders? Palaeogeography, Palaeoclimatology, Palaeoecology 223, 222-242.

Vörös, A. 2009: The Pliensbachian brachiopods of the Bakony Mountains (Hungary). Geologica Hungarica series Palaeontologica 58, 1-300.

Zezina, O.N. 1976: Ekologiia I Rasprostraneie Sovremennykh Brachiopod [The Ecology And Distribution of Present-day Brachiopods], 138 pp. Nauka, Moscow.

Zezina, O.N. 1985: Sovremennye Brakhiopody i Problemy Batial'noi Zony Okeana [Contemporary Brachiopods and Problems of the Bathyal Oceanic Zone], 248 pp. Nauka, Moscow. 